\title{
https://doi.org/10.46813/2021-131-122 \\ OPTICAL AND MASS SPECTRA FROM REACTIVE PLASMA AT MAGNETRON DEPOSITION OF TANTALUM OXYNITRIDE
}

\author{
S. Dudin, S. Yakovin, A. Zykov, N. Yefymenko \\ V.N. Karazin Kharkiv National University, Kharkiv, Ukraine \\ E-mail: dudin@karazin.ua
}

Processes in reactive plasma during the magnetron deposition of tantalum oxynitride with ICP activation of reactive gas are studied in dependence on Oxygen fraction. Results of spectroscopic study of optical emission from the plasma and of mass-spectrometry of gas composition in the vacuum chamber in response to ignition of magnetron discharge and inductively coupled plasma are presented. It is shown that dissociation level of all species grows with the magnetron current increase while its dependence on oxygen/nitrogen ratio is non-monotonic.

PACS: 52.77.-j, 81.15.-z

\section{INTRODUCTION}

Ta-based materials such as $\mathrm{Ta}_{2} \mathrm{O}_{5}, \mathrm{TaN}, \mathrm{TaON}$ have great potential as coatings for biomedical applications due to their excellent biocompatibility, corrosion resistance and stability.

In the studies carried out in [1-5], the formation of coatings from ternary oxynitride structures $\mathrm{TaO}_{\mathrm{x}} \mathrm{N}_{\mathrm{y}}$ was performed by the method of reactive magnetron sputtering at different flows of reactive gases, Oxygen and Nitrogen. In [1] photocatalytic and antibacterial properties of tantalum oxynitride obtained by the method of RF magnetron sputtering was investigated. In [2], the multiphase structure of stable $\left(\mathrm{Ta}_{2} \mathrm{~N}, \mathrm{Ta}_{3} \mathrm{~N}_{5}\right)$ and metastable ( $\mathrm{TaN}, \mathrm{Ta}_{4} \mathrm{~N}_{5}, \mathrm{Ta}_{3} \mathrm{~N}_{4}$ ) tantalum nitride compounds and its corrosion resistance were studied. In [3], the structural changes of the $\mathrm{TaO}_{\mathrm{x}} \mathrm{N}_{\mathrm{y}}$ system were investigated as a result of changes in its stoichiometry and photocatalytic properties.

The results of these studies demonstrate that, despite $\mathrm{TaO}_{\mathrm{x}} \mathrm{N}_{\mathrm{y}}$ compounds have common name, tantalum oxynitride, they demonstrate a wide range of modifications in the structure and elemental composition depending on the deposition conditions.

Most of the researchers focus on studying the properties of coatings. However, durimg reactive magnetron synthesis of such coatings, a complex set of processes in plasma occurs, which has not been studied in detail. Therefore, in this work, the physicochemical processes in plasma are investigated during the reactive magnetron deposition of tantalum oxynitride in the widest possible range of oxygen/nitrogen ratio.

\section{EXPERIMENTAL SETUP}

The experiments were carried out on the setup described elsewhere [6], using plasma activation of reactive gases $\left(\mathrm{O}_{2}, \mathrm{~N}_{2}\right)$ by inductively coupled plasma source (ICPS). The reactive gases was fed through the ICPS while Argon was injected to the vacuum chamber immediately, with the flow directed to the magnetron target. The Ar mass flow was $60 \mathrm{sccm}$ in all the experiments with Argon partial pressure of 1 mTorr. Variation of Oxygen fraction in the input gas mixture was carried out keeping total reactive gas flow constant. The total oxygen and nitrogen mass flow was $50 \mathrm{sccm}$. All the researched parameters were measured in dependence on Oxygen fraction in reactive gas input.
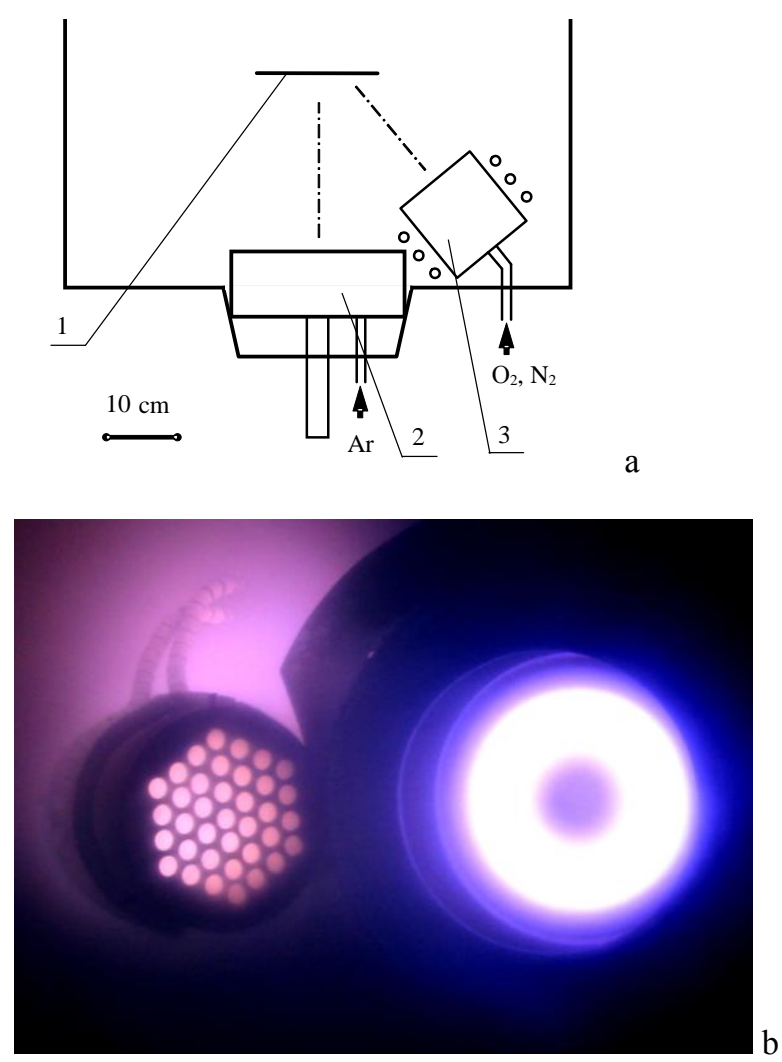

Fig. 1. Scheme of the experimental setup (1- substrate holder, 2 - magnetron, 3 -RF ICP source) (a);

Photo of the ICP source and magnetron discharge in simultaneous operation (b)

Mass-spectrometric research of the gas mixture sampled from the discharge chamber was performed using the ROMS-4 mass-spectrometer pumped by an ion pump with $100 \mathrm{l} / \mathrm{s}$ throughput.

To study optical emission from plasma, we used the spectrometer Horiba iHR-320 with 1800 lines/mm diffraction grating allowing the plasma emission spectrum measurement in the $200 \ldots 1000 \mathrm{~nm}$ range with resolution 
better than $1 \AA$. The optical fiber was equipped with a focusing lens placed at a fixed position outside the chamber at the distance of about $50 \mathrm{~cm}$ from the glowing plasmas. In the process of measurements the focus point was sequentially set in two different positions: ICP or magnetron plasma.

\section{EXPERIMENTAL RESULTS}

The first part of this section presents dependence of general discharge parameters on oxygen fraction in reactive gas mixture. Next part of the section describes the results of mass-spectrometry investigation of gas composition in the vacuum chamber in response to ignition of magnetron discharge and ICP. All the measurements were conducted in dependence on Oxygen fraction in reactive gas input. The final part exhibits the results of spectroscopic study of optical emission from the plasma during TaON coating deposition.

It is known that reactive gas addition to magnetron discharge changes the discharge voltage. Fig. 2 shows magnetron discharge parameters change in dependence on oxygen fraction variation. Magnetron voltage increases with the nitrogen replacement by oxygen. At the same time, magnetron current decreases keeping electrical power approximately constant.

During reactive magnetron sputtering, the growing film absorbs the reactive gas that can cause significant drop of partial pressure of reactive gas in the process chamber. Thus, the total gas pressure measured by a vacuummeter can drop down to the base argon pressure. One can see from the Fig. 2 that the gas pressure in the vacuum chamber decreases monotonically with the oxygen fraction increase. This means that oxygen is absorbed more effectively than nitrogen.

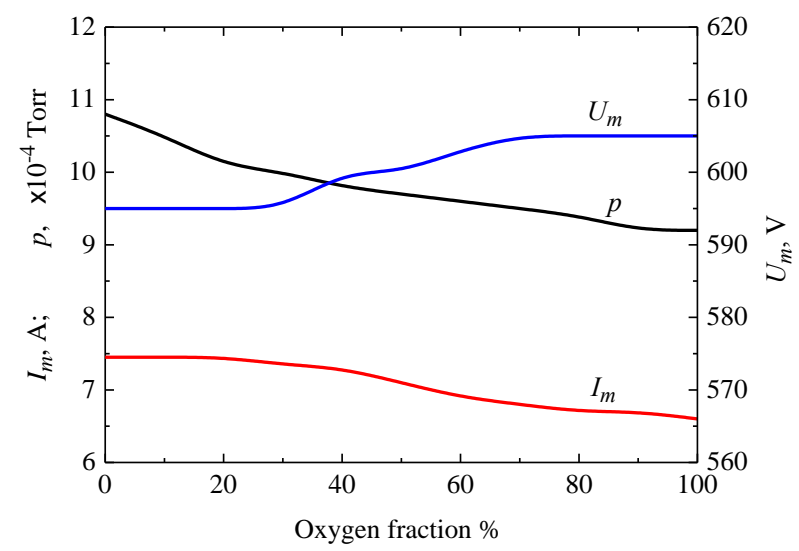

Fig. 2. Magnetron discharge parameters change in dependence on oxygen fraction in input reactive gas

Current-voltage characteristics of magnetron discharge at different Oxygen fractions are shown in the Fig. 3 in comparison with the corresponding characteristic without any reactive gas. It is well seen that reactive gas addition to magnetron discharge with tantalum target leads to magnetron voltage increase in contrast to Aluminium target case [6,7]. The characteristic for pure Oxygen exhibits non-monotonous $\mathrm{N}$-like shape.

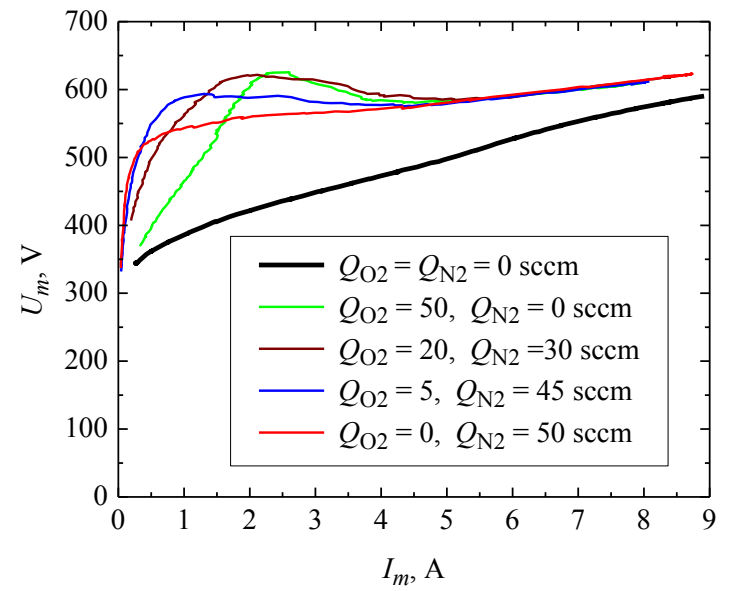

Fig. 3. Current-voltage characteristics of magnetron discharge at different oxygen fractions $\left(Q_{A r}=60 \mathrm{sccm}, P_{A r}=1.05\right.$ mTorr $)$

The changes in partial pressure of reactive gases noted above are also seen in mass-spectrum taken from the exhaust gas mixture (Fig. 4). Ignition of magnetron discharge reduces the both partial pressures of oxygen and nitrogen. Similarly to the pressure curve in Fig. 2, for the oxygen peak this phenomenon is more pronounced. Unexpectedly, the both peaks of oxygen and nitrogen decrease after ignition of ICPS. The reason for this is nitrogen oxide creation in plasma that is revealed by the peak growth of $M=30$.

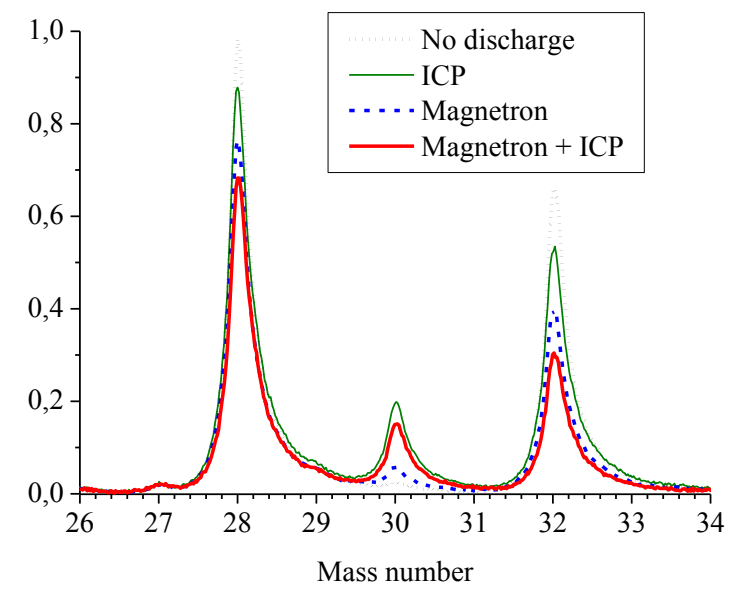

Fig. 4. Evolution of mass-spectrum of gas mixture in the vacuum chamber in response to ignition of different discharges (50\% oxygen, $50 \%$ nitrogen)

Fig. 5 shows the dependencies of $\mathrm{N}_{2}, \mathrm{O}_{2}$, and $\mathrm{NO}$ mass peak intensities on the oxygen fraction with both the ICPS and the magnetron discharge switched on as well as the same dependencies without plasma.

One can see that oxygen and nitrogen peaks are changed approximately proportionally to the correspondent gas fraction in the input flow. NO production rate is nearly constant at oxygen fractions of between 20 and $80 \%$ while decreases at the range limits due to lack of one of the reactants. 


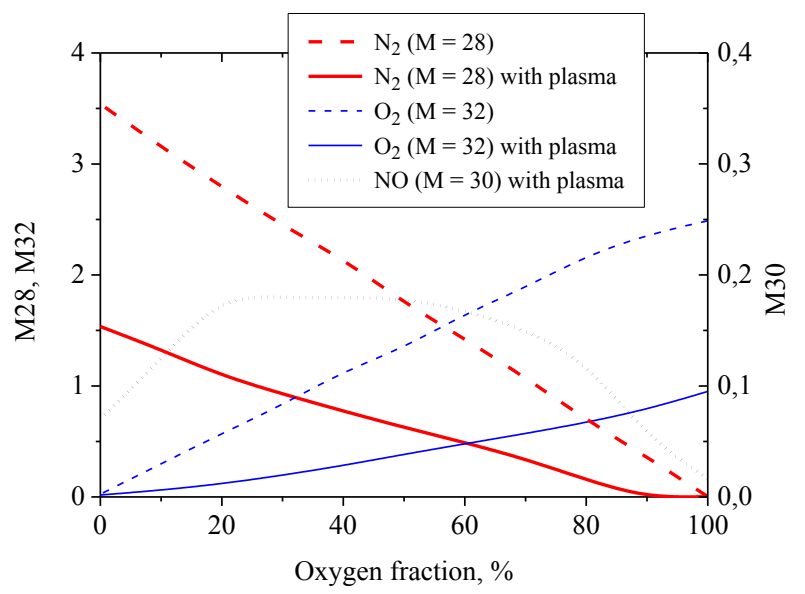

Fig. 5. Dependence of $\mathrm{N}_{2}, \mathrm{O}_{2}$, and $\mathrm{NO}$ mass peak intensities on the Oxygen fraction with and without plasma (magnetron discharge and ICP act simultaneously)

The reactive gas absorption ratio is also dependent on partial pressure of the gas. $\mathrm{N}_{2}$ and $\mathrm{O}_{2}$ absorption by the growing film and NO mass peak intensity in dependence on the oxygen fraction are shown in Fig. 6. Interesting fact is that the absorption of any reactive gas rises up to $100 \%$ at the lowest gas concentrations. Typical absorption values in the mid range are about $60 . .70 \%$, but the oxygen absorption is higher within the major part of the range.
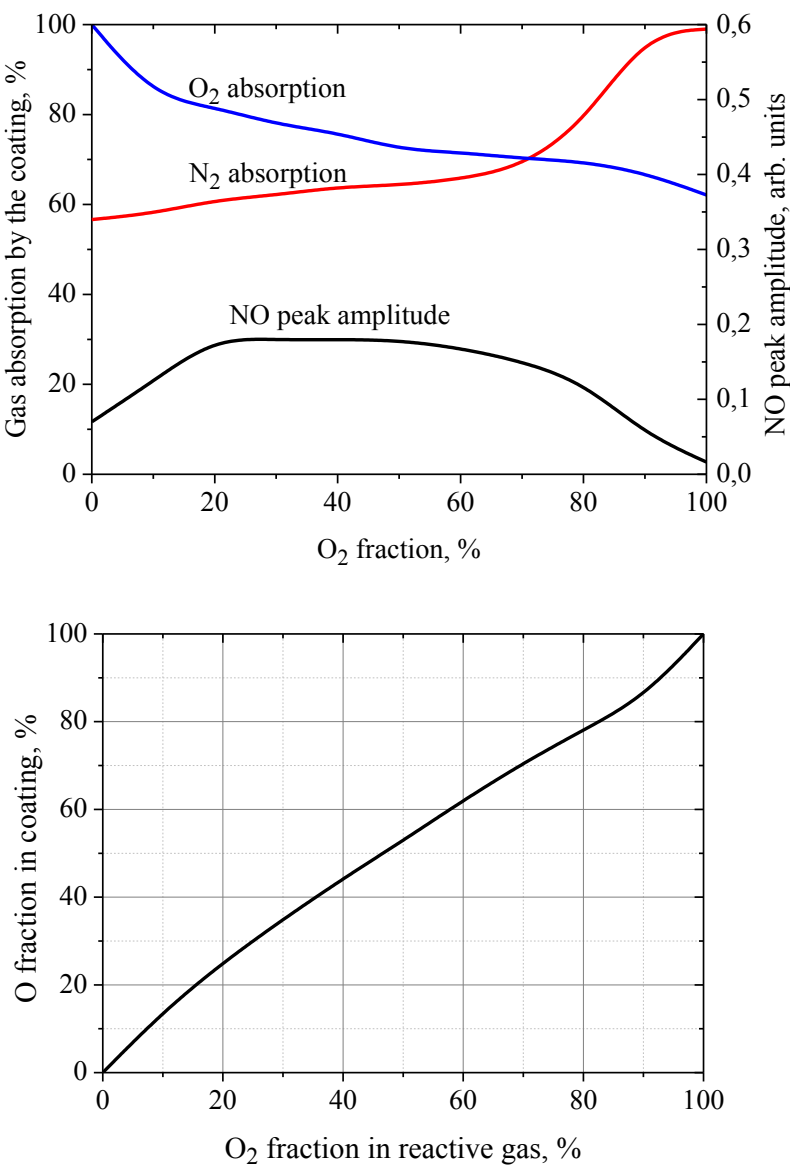

Fig. 6. $\mathrm{N}_{2}$ and $\mathrm{O}_{2}$ absorption by the growing film and NO mass peak intensity in dependence on the oxygen fraction
Since the reactive gas is absorbed by the growing film, this diagram allows estimation of content of the reactive gases in the $\mathrm{TaON}$ coating. It is seen from Fig. 6 that oxygen fraction in the film possesses almost the same value as the oxygen fraction in reactive gas, with slight nonlinearity. The reactive gas with lower concentration (both oxygen and nitrogen) is absorbed preferentially. Particularly, for the oxygen-nitrogen gas mixture, which is present in natural air $\left(21 \%\right.$ of $\left.\mathrm{O}_{2}\right)$, the gas flow ratio is about $4: 1$, but due to better oxygen absorption the resulting $\mathrm{N} / \mathrm{O}$ atom ratio in the film is $2.8: 1$ with mass ratio of 2.5:1.

Typical emission spectra from the magnetron plasma and ICPS during TaON coating deposition are shown in Fig. 7. One can see that the spectra are quite different. The ICP spectrum contains only the lines of gaseous species, while the major part of magnetron plasma spectrum is Tantalum emission. Further, for comparison of oxygen and nitrogen emission we shall use the lines $746.7 \mathrm{~nm}$ for nitrogen atom $357.4 \mathrm{~nm}$ for Nitrogen molecule and $777 \mathrm{~nm}$ for oxygen atom.

Fig. 8 presents dependencies of main peak intensities of magnetron discharge emission on the discharge current for different reactive gases: pure Oxygen, pure Nitrogen and their mixture. All the signals are normalized by the integral emission intensity over the full measured spectrum.
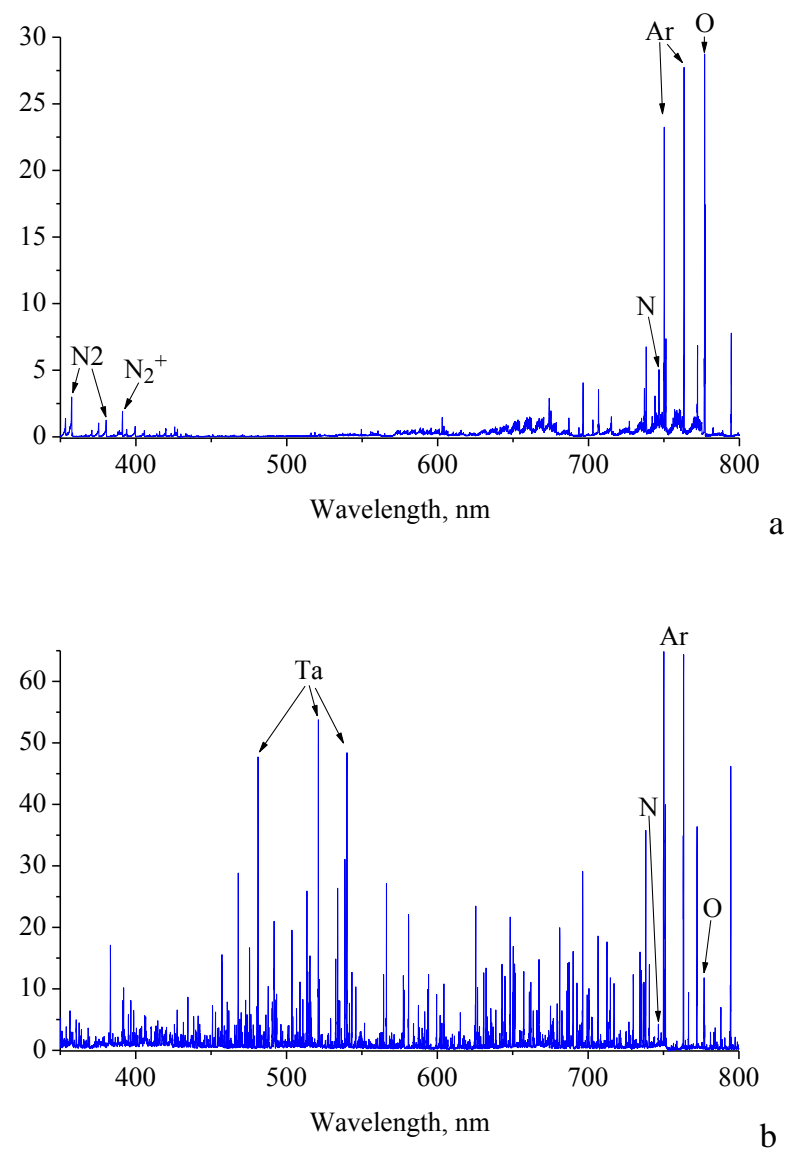

Fig. 7. Optical emission spectra from gas-discharge plasma: a-from ICP source; $b$-from magnetron discharge 

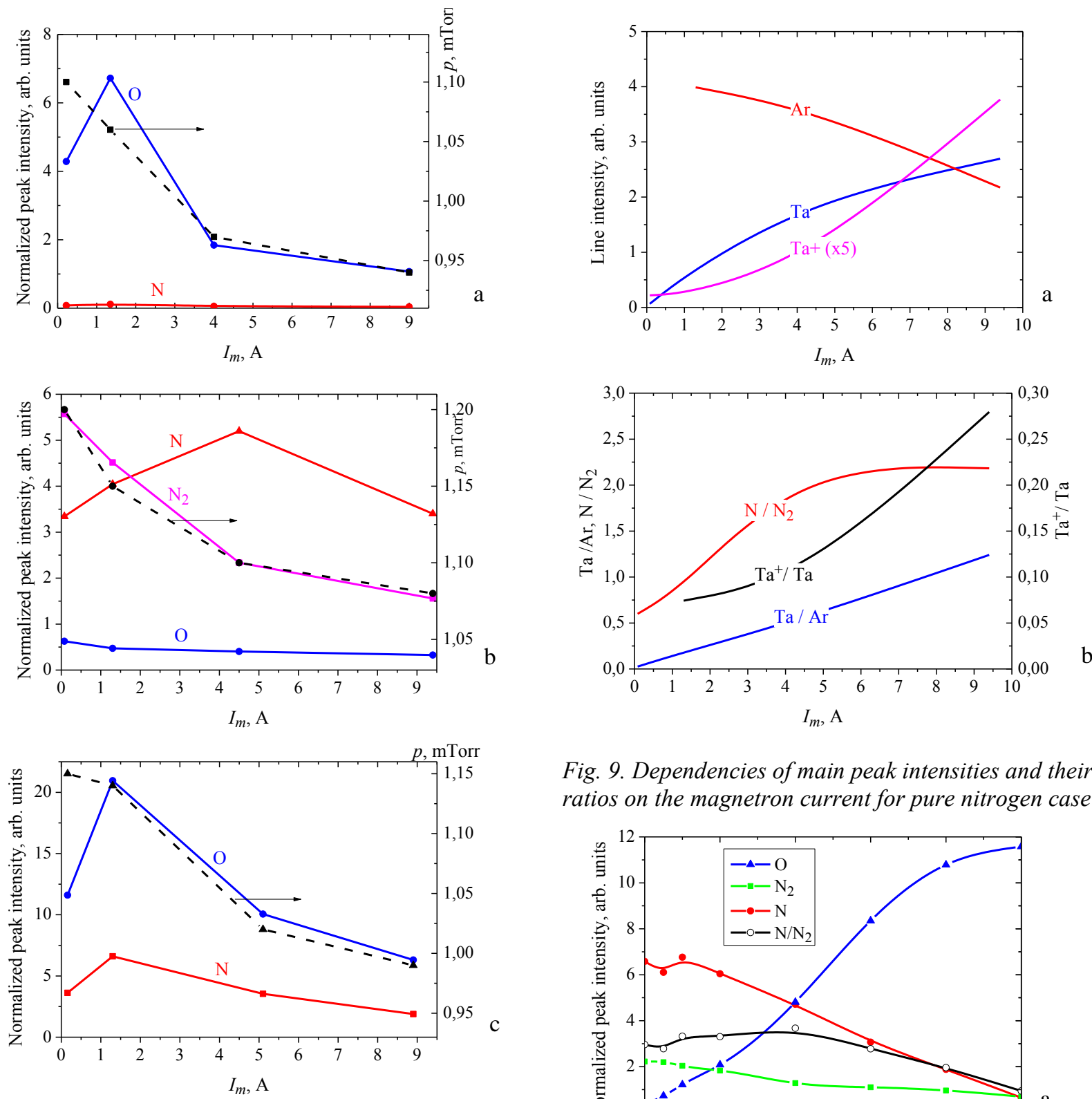

Fig. 8. Dependencies of main peak intensities of magnetron discharge emission on the discharge current with different reactive gas mixtures: a - pure oxygen; $b$-pure Nitrogen; $c-1: 1$ mixture of oxygen and nitrogen

One can see that the dependence of the atomic oxygen signal is non-monotonic (has a maximum), in contrast to the pressure, which changes monotonically. At low currents, there is a lot of oxygen, but the fraction of atomic oxygen is small. At higher magnetron currents, the atomic oxygen signal decreases in correlation with the pressure drop caused by the oxygen absorption by the growing film. Atomic nitrogen demonstrates similar behaviour, but with the peak shifted to higher currents. For oxygen/nitrogen mixture, the picture looks similar to the pure Oxygen case.

Dependencies of peak intensities of $\mathrm{Ar}, \mathrm{Ta}, \mathrm{Ta}+$ on the magnetron current for pure nitrogen case are shown in Fig. 9,a. Argon emission decreases with the current increase while tantalum emission is growing. Ionized tantalum line intensity grows much faster at high current.

Fig. 9. Dependencies of main peak intensities and their ratios on the magnetron current for pure nitrogen case
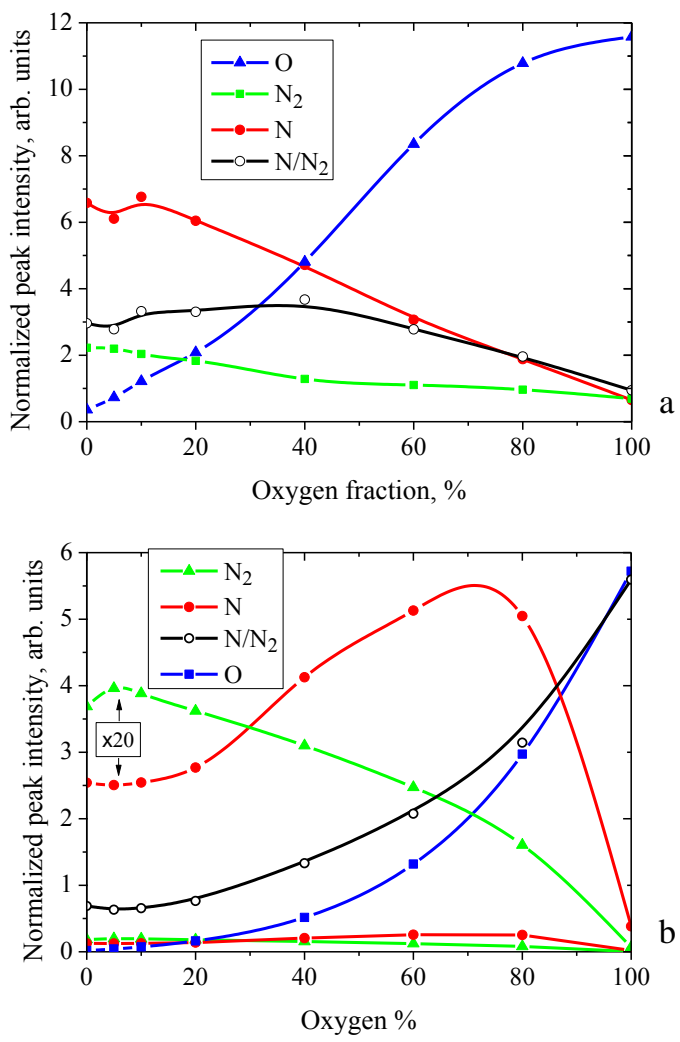

Fig. 10. Dependencies of main peak intensities and their ratios on oxygen fraction in reactive gas:

$a$-from magnetron discharge; $b$-from ICP source

In order to find regularities in these dependencies the main peak ratios are plotted in Fig. 9,b. One can see that 
nitrogen dissociation, tantalum ionization and $\mathrm{Ta} / \mathrm{Ar}$ ratio are growing functions versus magnetron current. At high currents significant part of ions bombarding the magnetron target are the $\mathrm{Ta}^{+}$rather than $\mathrm{Ar}^{+}$ions.

Fig. 10 presents the main peak intensities and their ratios in dependence on the oxygen fraction in reactive gas. The results are shown separately for magnetron discharge and ICP source. In magnetron plasma, the $\mathrm{O}$ and $\mathrm{N}$ peaks change in correlation with the correspondent gas species concentration in the input mixture while nitrogen dissociation ratio shows non-monotonic dependence. In ICP, the emission of nitrogen and oxygen atoms depends non-linearly on the reactive gas composition. Atomic nitrogen emission even grows with $\mathrm{N}_{2}$ fraction reduction down to $20 . .30 \%$. The atomic oxygen signal demonstrates parabolic dependence on the molecular oxygen fraction. The $\mathrm{N} / \mathrm{N}_{2}$ ratio increases by almost an order of magnitude after the oxygen fraction change from 0 to $100 \%$.

\section{CONCLUSIONS}

Thus, we have studied processes in reactive plasma during the magnetron deposition of tantalum oxynitride with ICP activation of reactive gas. The research results show that the plasmas of magnetron discharge and of inductively coupled plasma source are well separated in chemical sense. Mass-spectrometric investigation of gas mixture in the vacuum chamber in response to ignition of magnetron discharge and inductively coupled plasma show that the plasma ignition changes the gas composition dramatically. Oxygen and nitrogen partial pressures are reduced due to generation of nitrogen oxide in ICP and due to reactive gas absorption by condensing film. It has been shown that the oxygen fraction in the film is almost the same as the oxygen fraction in reactive gas, but with slight nonlinearity. Optical emission spectros- copy has allowed to investigate dissociation and ionization dependencies on the oxygen fraction. It is shown that dissociation level of all species grows with the magnetron current increase while its dependence on oxygen/nitrogen ratio is non-monotonic.

\section{REFERENCES}

1. Daniel Cristea et al. Tantalum Oxynitride Thin Films: Assessment of the Photocatalytic Efficiency and Antimicrobial Capacity // Nanomaterials. 2019, № 9, p. 476. 2. L. Mendizabal et al. Effect of N2 flow rate on the microstructure and electrochemical behavior of $\mathrm{TaNx}$ films deposited by modulated pulsed power magnetron sputtering // Thin Solid Films. 2016, v. 610, p. 1-9.

3. Christine Taviot-Guého et.. al. Multiphase Structure of Tantalum Oxynitride TaOxNy Thin Films Deposited by Reactive Magnetron Sputtering // J. Phys. Chem. C. 2015, v. 119, p. 23559-23571.

4. Angelique Bousquet et. al. Control the Composition of Tantalum Oxynitride Films by Sputtering a Tantalum Target in $\mathrm{Ar} / \mathrm{O}_{2} / \mathrm{N}_{2}$ Radiofrequency Magnetron Plasmas // Plasma Process. Polym. 2013, v. 10 (11), p. 990.

5. A Zykova, V Safonov, S Yakovin, et. al. Comparative analysis of platelets adhesion to the surface of Tabased ceramic coatings deposited by magnetron sputtering // J. Phys.: Conf. Ser. 2020, v. 1492, p. 012038.

6. S. Yakovin, S. Dudin, A. Zykov, V. Farenik. Integral cluster set-up for complex compound composites syntesis // Problems of Atomic Science and Technology. Series «Plasma Physics». 2011, № 1, p. 152-154.

7. A.V. Zykov, S.D. Yakovin, S.V. Dudin. Synthesis of dielectric compounds by DC magnetron // Physical Surface Engineering. 2009, v. 7, № 3, p. 195-203.

Article received 12.01.2021

\title{
ОПТИЧЕСКИЕ И МАССОВЫЕ СПЕКТРЫ РЕАКТИВНОЙ ПЛАЗМЫ ПРИ МАГНЕТРОННОМ НАНЕСЕНИИ ОКСИНИТРИДА ТАНТАЛА
}

\author{
С. Дудин, С. Яковин, А. Зыков, Н. Ефименко
}

Изучены процессы в реактивной плазме при магнетронном осаждении оксинитрида тантала с ICPактивацией реактивного газа в зависимости от процентного содержания кислорода. Приведены результаты спектроскопических исследований оптического излучения плазмы и масс-спектрометрии состава газа в вакуумной камере при зажигании магнетронного разряда и индуктивно связанной плазмы. Показано, что уровень диссоциации всех молекул растет с увеличением тока магнетрона, а его зависимость от соотношения кислород/азот немонотонна.

\section{ОПТИЧНІ ТА МАСОВІ СПЕКТРИ РЕАКТИВНОЇ ПЛАЗМИ ПРИ МАГНЕТРОННОМУ НАНЕСЕННІ ОКСИНІТРИДУ ТАНТАЛУ}

\section{С. Дудін, С. Яковін, О. Зиков, Н. Сфименко}

Вивчаються процеси в реактивній плазмі під час магнетронного осадження оксинітриду танталу 3 ICPактивацією реактивного газу залежно від частки кисню. Представлені результати спектроскопічного дослідження оптичного випромінювання з плазми та мас-спектрометрії газового складу у вакуумній камері у відповідь на запалювання магнетронного розряду та індуктивно зв'язаної плазми. Показано, що рівень дисоціації всіх молекул зростає із збільшенням струму магнетрона, тоді як його залежність від співвідношення кисень/азот є немонотонною. 